\title{
Effect of Integrated Nutrient Management on Growth of Wheat (Triticum aestivum) Cultivars
}

\author{
R.R. Choudhary*, H.L. Yadav, S.L. Choudhary, A.L. Prajapat and Ritu Choudhary \\ Sri Karan Narendra Agriculture University, Jobner (Rajasthan), India \\ *Corresponding author
}

A B S T R A C T

The field experiment was conducted at research farm, Rajasthan

Keywords

Wheat, Integrated nutrient management, Varieties and Growth attributes.

Article Info

Accepted:

21 June 2017

Available Online:

10 August 2017
Agricultural Research Institute, Durgapura, Jaipur for two consecutive years during rabi seasons 2014-15 and 2015-16 on loamy sand soil. The twenty four treatment combinations consisting of four varieties and six integrated nutrient management practices were tested in factorial randomized block design with three replications. Results showed that variety WH 1105 proved significantly superior over HD 2967 and PBW 502 varieties with respect to growth attributes viz. Plant height, dry matter accumulation, LAI, LAD, CGR, RGR and NAR and closely followed by variety Raj 4037. Results further indicated that plant height, dry matter accumulation, dry matter translocation, dry matter translocation efficiency, LAI, LAD, CGR, RGR and NAR significantly increased with application of $100 \% \mathrm{RDF}+$ Azotobacter + PSB over farmer's practice but remained at par with $100 \%$ RDF.

\section{Introduction}

Wheat [Triticum aestivum (L.) emend. Fiori \& Paol.] Is the most important staple food crop of the world and emerged as the backbone of India's food security. It is grown all over the world for its wider adaptability and high nutritive value. It is an important winter cereal contributing about $38 \%$ of the total food grain production in India. Wheat straw is an important source of fodder for a large Indian animal population in India. Wheat and rice serve as life sustaining crops for our population and thus, considered to be the cornerstone of nation's food security system. However, there is need to further increase the production to fulfill the requirement of exploding population, maintenance of adequate buffer stock and to meet out demand for processing industries. The rice-wheat cropping system of Indian agriculture is the cornerstone of the nation's food security. This system contributes about 75 percent of the nation's total food grain production (Yadav et al., 2005). It has tremendously helped the socio-economic development of the rural population in India. The green revolution in India during the late 1960s has no doubt brought about selfsufficiency in food grain production. But currently, there is a growing concern about the sustainability of the rice-wheat cropping 
system as the growth rates of rice and wheat yields have either become stagnant or declined in rice-wheat growing states like Punjab, Haryana, eastern Uttar Pradesh, Madhya Pradesh, Bihar, Himachal Pradesh, Jammu and Kashmir as well as southern and other states. The dwarf varieties of wheat have great potential but due to exhaustive nature they require more nutrients and have posed a great threat to long-term sustainability of crop production.

\section{Materials and Methods}

The field experiment was conducted at research farm, Rajasthan Agricultural Research Institute, Durgapura, Jaipur for two consecutive years during rabi seasons 201415 and 2015-16. The twenty four treatment combinations consisting of four varieties viz. PBW 502, Raj 4037, WH 1105 and HD 2967 and six integrated nutrient management practices viz. Farmer's practice, $100 \%$ RDF, $100 \% \mathrm{RDF}+$ Azotobacter + PSB, $75 \% \mathrm{RDF}$ + Azotobacter + PSB, $75 \%$ RDF + Azotobacter + PSB + ZnSO4 and $50 \% \mathrm{RDF}$ $+25 \% \mathrm{~N}$ through organic manure + Azotobacter $+\mathrm{PSB}+\mathrm{ZnSO} 4$ were tested in Factorial Randomized Block Design (FRBD) with three replications. The treatments were randomly allotted to different plots using random number table of Fisher and Yates (1963). The soil of the experimental site was loamy sand with bulk density of $1.55 \mathrm{~g} / \mathrm{cm}$ and field capacity of $9.7 \%(\mathrm{w} / \mathrm{w})$. It had $0.25 \%$ organic carbon, $140.5 \mathrm{~kg} \mathrm{KMnO} 4$ oxidizable N/ha, $27.6 \mathrm{~kg} 0.5 \mathrm{~N} \mathrm{NaHCO} 3$ $\begin{array}{llllll}\text { extractable } & \mathrm{P}_{2} \mathrm{O}_{5} / \mathrm{ha}, & 186.5 & \mathrm{~kg} & 1.0 & \mathrm{~N}\end{array}$ NH4OAC-exchangeable $\mathrm{K}_{2} \mathrm{O} / \mathrm{ha}, 0.58 \mathrm{mg}$ DTPA-extractable available $\mathrm{Zn} / \mathrm{kg}$ soil, 8.2 $\mathrm{pH}$ and $0.14 \mathrm{dS} / \mathrm{m}$ electrical conductivity at the start of the experiment. The recommended doses of fertilizers, i.e. 150:60:40 N, $\mathrm{P}_{2} \mathrm{O}_{5}$ and $\mathrm{K}_{2} \mathrm{O} \mathrm{kg} / \mathrm{ha}$ was applied to wheat as per the treatment and 80:40: $\mathrm{N}$ and $\mathrm{P}_{2} \mathrm{O}_{5} \quad \mathrm{~kg} / \mathrm{ha}$ applied as farmer's practice. Five plants were selected randomly from net plot for the measurements of plant height, dry matter accumulation and leaf-area index of wheat and $0.5 \mathrm{~m}^{2}$ area was selected for the measurement of dry-matter accumulation and leaf area index. Leaf-area was measured by using leaf-area meter. Leaf area index was computed by dividing the leaf area to ground area. The data collected for different parameters were statistically analysed using the F-test as per the procedure given by Gomez and Gomez (1984) for factorial randomized block design. The results are presented at $5 \%$ level of significance $(\mathrm{P}=0.05)$ for making comparison between treatments.

\section{Results and Discussion}

Data (Tables 1 and 2) revealed that wheat variety WH 1105 recorded higher plant height, dry matter accumulation, dry matter translocation, dry matter translocation efficiency, leaf area index (LAI), leaf area duration (LAD), crop growth rate (CGR), relative growth rate (RGR) and net assimilation rate (NAR), which was found at par with variety Raj 4037 in pooled analysis. Data (Tables 1 and 2) further indicated that application of $100 \% \mathrm{RDF}+$ Azotobacter + PSB significantly increased growth attributes, leaf area index, leaf area duration, crop growth rate, relative growth rate and net assimilation rate on pooled analysis over farmer's practice and was found at par with $100 \%$ RDF.

The overall improvement in crop growth under the influence of optimum nutrition involving combination of all nutrients and increasing role of fertility levels could be ascribed to their potential role in modifying soil and plant environment conducive for better development of both physiological and biochemical components of the plant growth that increase efficiency of physiological processes of plant system. Amongst nutrients, nitrogen is considered to be a vitally important plant nutrient. 
Table.1 Effect of varieties and integrated nutrient management on plant height, dry matter accumulation, dry mater translocation and dry matter translocation efficiency of wheat (Pooled data of 2 years)

\begin{tabular}{|c|c|c|c|c|c|c|c|c|}
\hline \multirow[t]{2}{*}{ Treatments } & \multicolumn{3}{|c|}{ Plant height (cm) } & \multicolumn{3}{|c|}{ Dry matter accumulation (g/plant) } & \multirow{2}{*}{$\begin{array}{c}\text { Dry matter } \\
\text { translocation } \\
\left(\text { g plant }^{-1}\right)\end{array}$} & \multirow{2}{*}{$\begin{array}{l}\text { Dry matter } \\
\text { translocation } \\
\text { efficiency }(\%)\end{array}$} \\
\hline & 60 DAS & $\begin{array}{c}90 \\
\text { DAS }\end{array}$ & $\begin{array}{c}\text { At } \\
\text { harves } \\
\mathbf{t}\end{array}$ & 60 DAS & 90 DAS & $\begin{array}{l}\text { At physiological } \\
\text { maturity }\end{array}$ & & \\
\hline \multicolumn{9}{|l|}{ Varieties } \\
\hline PBW 502 & 37.1 & 76.7 & 79.2 & 2.23 & 9.89 & 11.51 & 0.67 & 6.79 \\
\hline Raj 4037 & 42.2 & 88.3 & 90.6 & 2.44 & 11.00 & 12.64 & 0.77 & 7.40 \\
\hline WH 1105 & 42.6 & 89.2 & 91.3 & 2.46 & 11.16 & 12.86 & 0.79 & 7.45 \\
\hline HD 2967 & 39.7 & 82.6 & 85.8 & 2.34 & 10.47 & 12.01 & 0.72 & 7.09 \\
\hline $\mathrm{SEm} \pm$ & 0.44 & 1.08 & 1.07 & 0.02 & 0.11 & 0.12 & 0.01 & 0.07 \\
\hline $\mathrm{CD}(\mathrm{P}=0.05)$ & 1.24 & 3.03 & 3.01 & 0.06 & 0.29 & 0.33 & 0.02 & 0.20 \\
\hline \multicolumn{9}{|l|}{ Integrated nutrient management } \\
\hline Farmer's practice & 35.6 & 73.9 & 76.1 & 2.12 & 9.47 & 10.91 & 0.62 & 6.42 \\
\hline $100 \% \mathrm{RDF}$ & 43.3 & 90.7 & 93.2 & 2.51 & 11.32 & 13.09 & 0.80 & 7.65 \\
\hline $100 \% \mathrm{RDF}+$ Azotobacter $+\mathrm{PSB}$ & 43.9 & 90.9 & 93.5 & 2.55 & 11.46 & 13.36 & 0.83 & 7.69 \\
\hline $75 \% \mathrm{RDF}+$ Azotobacter $+\mathrm{PSB}$ & 38.1 & 79.5 & 82.0 & 2.24 & 10.11 & 11.54 & 0.68 & 6.82 \\
\hline $75 \% \mathrm{RDF}+$ Azotobacter $+\mathrm{PSB}+\mathrm{ZnSO}_{4}$ & 40.5 & 84.9 & 87.7 & 2.38 & 10.66 & 12.17 & 0.73 & 7.23 \\
\hline $\begin{array}{l}50 \% \mathrm{RDF}+25 \% \mathrm{~N} \text { through organic manure } \\
+ \text { Azotobacter }+\mathrm{PSB}+\mathrm{ZnSO}_{4}\end{array}$ & 40.9 & 85.4 & 87.9 & 2.40 & 10.77 & 12.46 & 0.74 & 7.26 \\
\hline SEm \pm & 0.54 & 1.32 & 1.31 & 0.03 & 0.13 & 0.23 & 0.01 & 0.09 \\
\hline $\mathrm{CD}(\mathrm{P}=0.05)$ & 1.52 & 3.72 & 3.69 & 0.08 & 0.36 & 0.65 & 0.03 & 0.25 \\
\hline
\end{tabular}

$\mathrm{RDF}=$ recommended dose of fertilizer; DAS = days after sowing 
Table.2 Effect of varieties and integrated nutrient management on leaf area index, leaf area duration, crop growth rate, net assimilation rate and relative growth rate (Pooled data of 2 years)

\begin{tabular}{|c|c|c|c|c|c|c|c|c|c|c|c|}
\hline \multirow[t]{2}{*}{ Treatments } & \multicolumn{3}{|c|}{ LAI } & \multicolumn{2}{|c|}{ LAD (Days) } & \multicolumn{2}{|c|}{ CGR $\left(\mathrm{gm}^{-2} \mathrm{day}^{-1}\right)$} & \multicolumn{2}{|c|}{$\begin{array}{c}\text { NAR } \\
\left(\text { gm }^{-2} \text { leaf area }\right. \\
\left.\text { day }^{-1}\right)\end{array}$} & \multicolumn{2}{|c|}{$\operatorname{RGR}\left(\mathrm{mg} \mathrm{g}_{1} \mathrm{~g}^{-1} \mathrm{day}^{-}\right.$} \\
\hline & 30 DAS & 60 DAS & $\begin{array}{c}90 \\
\text { DAS }\end{array}$ & $\begin{array}{c}\text { 30-60 } \\
\text { days } \\
\text { phase }\end{array}$ & $\begin{array}{c}60-90 \\
\text { days } \\
\text { phase }\end{array}$ & $\begin{array}{c}30-60 \\
\text { days } \\
\text { phase }\end{array}$ & $\begin{array}{c}60-90 \\
\text { days } \\
\text { phase }\end{array}$ & $\begin{array}{l}\text { 30-60 days } \\
\text { phase }\end{array}$ & $\begin{array}{c}60-90 \\
\text { days } \\
\text { phase }\end{array}$ & $\begin{array}{c}\text { 30-60 } \\
\text { days } \\
\text { phase }\end{array}$ & $\begin{array}{c}60-90 \\
\text { days } \\
\text { phase }\end{array}$ \\
\hline \multicolumn{12}{|l|}{ Varieties } \\
\hline PBW 502 & 0.59 & 2.32 & 4.05 & 43.6 & 95.5 & 6.10 & 25.50 & 3.41 & 5.58 & 55.9 & 42.8 \\
\hline Raj 4037 & 0.62 & 2.57 & 4.56 & 47.8 & 106.9 & 6.80 & 28.60 & 3.51 & 5.83 & 56.5 & 46.0 \\
\hline WH 1105 & 0.62 & 2.60 & 4.61 & 48.3 & 108.1 & 6.80 & 29.00 & 3.53 & 5.85 & 57.2 & 47.0 \\
\hline HD 2967 & 0.61 & 2.45 & 4.28 & 45.9 & 100.9 & 6.50 & 27.10 & 3.46 & 5.80 & 56.7 & 44.4 \\
\hline $\mathrm{SEm} \pm$ & 0.01 & 0.02 & 0.04 & 0.45 & 0.90 & 0.09 & 0.22 & 0.05 & 0.04 & 0.8 & 0.6 \\
\hline $\mathrm{CD}(\mathrm{P}=0.05)$ & NS & 0.07 & 0.12 & 1.25 & 2.52 & 0.25 & 0.61 & NS & 0.11 & NS & 1.8 \\
\hline \multicolumn{12}{|l|}{$\begin{array}{l}\text { Integrated nutrient } \\
\text { management }\end{array}$} \\
\hline Farmer's practice & 0.58 & 2.19 & 3.88 & 41.5 & 91.0 & 5.70 & 24.50 & 3.35 & 5.43 & 55.7 & 39.8 \\
\hline $100 \% \mathrm{RDF}$ & 0.63 & 2.66 & 4.70 & 49.3 & 110.4 & 7.00 & 29.30 & 3.56 & 5.93 & 57.2 & 48.1 \\
\hline $\begin{array}{l}100 \% \mathrm{RDF}+\text { Azotobacter }+ \\
\text { PSB }\end{array}$ & 0.63 & 2.68 & 4.72 & 49.6 & 111.0 & 7.10 & 29.70 & 3.59 & 5.95 & 57.5 & 48.4 \\
\hline $75 \% \mathrm{RDF}+$ Azotobacter $+\mathrm{PSB}$ & 0.60 & 2.36 & 4.14 & 44.4 & 97.5 & 6.10 & 26.20 & 3.41 & 5.64 & 55.9 & 43.0 \\
\hline $\begin{array}{l}75 \% \mathrm{RDF}+\text { Azotobacter }+\mathrm{PSB} \\
+\mathrm{ZnSO}_{4}\end{array}$ & 0.61 & 2.50 & 4.38 & 46.6 & 103.2 & 6.60 & 27.60 & 3.46 & 5.77 & 56.3 & 45.4 \\
\hline $\begin{array}{l}50 \% \mathrm{RDF}+25 \% \mathrm{~N} \text { through } \\
\text { organic manure }+ \text { Azotobacter }+ \\
\mathrm{PSB}+\mathrm{ZnSO}_{4}\end{array}$ & 0.62 & 2.52 & 4.41 & 47.1 & 103.9 & 6.60 & 27.90 & 3.48 & 5.84 & 56.7 & 45.6 \\
\hline $\mathrm{SEm} \pm$ & 0.01 & 0.03 & 0.05 & 0.60 & 1.20 & 0.08 & 0.30 & 0.06 & 0.05 & 1.0 & 0.8 \\
\hline $\mathrm{CD}(\mathrm{P}=0.05)$ & NS & 0.08 & 0.15 & 1.75 & 3.45 & 0.22 & 0.90 & NS & 0.14 & NS & 2.1 \\
\hline
\end{tabular}


It is necessary for chlorophyll synthesis and as a part of the chlorophyll molecule, which is the primary absorber of light energy needed for photosynthesis. Lack of $\mathrm{N}$ and chlorophyll means the crop will not utilize sunlight as an energy source to carry on essential function such as nutrient uptake. It is a component of vitamins and energy systems in plants. Nitrogen is an essential component of amino acids, which form plant proteins. Besides these, it is also a constituent of certain organic compounds of physiological importance (Brady and Well, 2002; Havlin et al., 2006).

The improvement in these growth parameters might have led to higher interception and absorption of radiant energy, resulting into greater photosynthesis and finally dry matter accumulation (Sharma et al., 2000). It is established that for realizing growth potential of a plant to the fullest extent, its life cycle should match with the growing season and timing of its major growth stages should coincide with required sequence of climatic conditions. Thus, the inherent capabilities of variety WH 1105 with enhanced vegetative growth with optimum duration available under prevailing climatic conditions might have helped the plants to efficiently utilize prevailing climatic conditions. Whereas, the other varieties faced adverse climatic conditions, especially the maturity period which coincided with higher temperature resulting into forced Variety Raj 4037 was also comparable to WH 1105 as evident from its capacity to produce similar dry matter.

The marked variations in growth and development between varieties have been noticed by Kumar et al., (1998), Srinivas (2002), Jat and Singhi (2004) and Singh et al., (2010). Hence, results of present investigation are also in cognizance with those of above workers. Effect of integrated nutrient management on various growth parameters of the crop appears to be on account of enrichment of available soil nutrients for growth and development of plant right from early stage. Thus better nutritional environment under integrated nutrient management seems to have promoted height of plants and growth of individual leaf by way of active cell division and elongation and even improved chlorophyll synthesis. The larger canopy development and plant height under the application of higher dose of integrated nutrient management might have increased interception, absorption and utilization of solar energy which in turn increased overall growth, photosynthesis and finally accumulation of dry matter plant ${ }^{-1}$. The positive correlation between dry matter accumulations at physiological maturity (0.967) is also a testimony of this fact. The beneficial effect of integrated nutrient management involving primary nutrients (NPK) on plant height and dry matter accumulation was also observed by several researchers on wheat (Seoran et al., 2009; Sharma and Sharma, 2013).

\section{References}

Yadav, D.S., Shukla, R.P. and Birendra, K. 2005. Effect of zero tillage and nitrogen levels on wheat (Triticum aestivum) after rice (Oryza sativa). Indian Journal of Agronomy 50(1): 52-53.

Gomez, K. A. and Gomez, A. A. 1984. Statistical Procedures for Agricultural Research, pp 97-107. John Willey \& Sons, New York.

Fisher, R.A. and Yates, F. 1963. Statistical tables. Oliver and Boyd, Edinburgh, London.

Brady, N.C. and Well, R.R. 2002. The nature and properties of soil (13 ${ }^{\text {th }}$ Edition), Pearson Education (Singapore) Pvt. Ltd., New Delhi, India.

Havlin, J.L., Beaton, J.D., Tisdale, S.L., Nelson, W.L., 2006. Soil fertility and fertilizer 7th Edition, Prentice Hall of 
India Pvt. Ltd., New Delhi pp. 45-79.

Sharma, A., Karambir, N. and Singh, M. 2000. Effect of sowing time on radiation use efficiency of wheat cultivars. Journal of Agro meteorology 2: 166-169.

Kumar, S., Bangwara, A.S., Singh, D.P. and Phogat, S.B. 1998. Dry matter accumulation in dwarf wheat varieties under different nitrogen levels and sowing dates. Haryana Agricultural University Journal of Research 28: 151157.

Srinivas, A. 2002. Influence of nitrogen and methods of Zinc application on growth and Yield of Wheat (Triticum aestivum) varieties. Indian Journal of Agricultural Research 36(3): 167-171.

Jat, L.N. and Singhi, S.M. 2004. Growth, yield attributes and yields of wheat (Triticum aestivum) under different planting pattern or cropping systems and varieties. Indian Journal of
Agronomy 49(2): 111-113.

Singh, P., Singh, P., Singh, K.N., Singh, R., Aga, F.A., Bahar, F. and Raja, W. 2010. Evaluation of Wheat (Triticum aestivum) genotype for productivity and economics under graded levels of nitrogen in temperature Kashmir. Indian Journal of Agricultural Sciences 80(5): 380-384.

Seoran, P., Sardana, V., Singh, S., Bhushaan, B., Bawa, S.S. and Singh, C.B. 2009. Long - term effect of tillage and nitrogen sources on the sustainability and productivity of maize (Zea mays) wheat (Triticum aestivum) cropping system under rainfed condition. Indian Journal of Agricultural Sciences 79: 259-63.

Sharma, R. and Sharma, H.L. 2013. Effect of long term integrated nutrient management system on soil and crop productivity in rice wheat crop sequence. Shodh Gangas 7(1): 21-26

\section{How to cite this article:}

Choudhary, R.R., H.L. Yadav, S.L. Choudhary, A.L. Prajapat and Ritu Choudhary. 2017. Effect of Integrated Nutrient Management on Growth of Wheat (Triticum aestivum) Cultivars. Int.J.Curr.Microbiol.App.Sci. 6(8): 2369-2374. doi: https://doi.org/10.20546/ijcmas.2017.608.280 